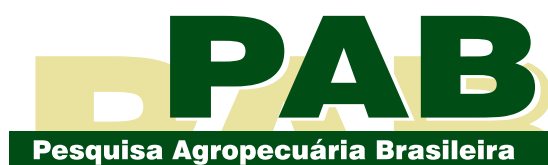

ISSN 1678-3921

Journal homepage: www.embrapa.br/pab

For manuscript submission and journal contents, access: www.scielo.br/pab

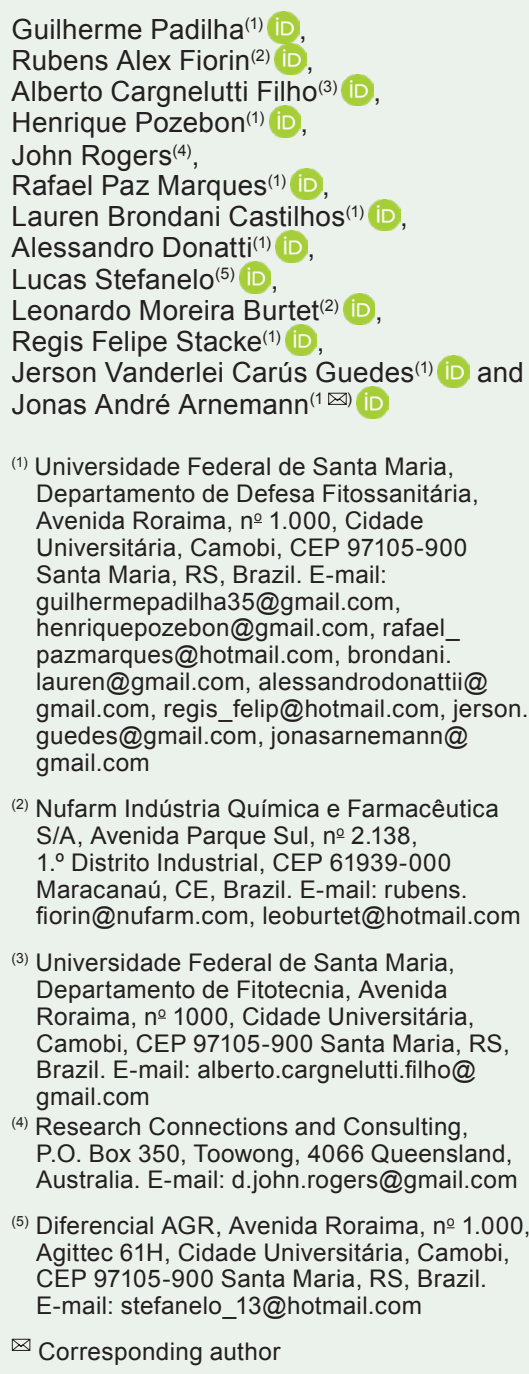

(3) Universidade Federal de Santa Maria, Departamento de Fitotecnia, Avenida Roraima, o 1000, Cidade Universitária, Camobi, CEP 97105-900 Santa Maria, RS, Brazil. E-mail: alberto.cargnelutti.filho@ gmail.com

(4) Research Connections and Consulting, P.O. Box 350, Toowong, 4066 Queensland, Australia. E-mail: d.john.rogers@gmail.com

(5) Diferencial AGR, Avenida Roraima, № 1.000 Agittec $61 \mathrm{H}$, Cidade Universitária, Camobi, CEP 97105-900 Santa Maria, RS, Brazil. E-mail: stefanelo_13@hotmail.com

$\bowtie$ Corresponding author

Received

February 28, 2020

Accepted

August 25, 2020

How to cite

PADILHA, G.; FIORIN, R.A.; FILHO, A.C.; POZEBON, H.; ROGERS, J.; MARQUES, R.P.; CASTILHOS, L.B.; DONATTI, A.; STEFANELO, L.; BURTET, L.M.; STACKE, R.F.; GUEDES, J.V.C.; ARNEMANN, J.A. Damage assessment and economic injury level of the two-spotted spider mite Tetranychus urticae in soybean. Pesquisa Agropecuária Brasileira, v.55, e01836, 2020. DOI: https://doi.org/10.1590/ S1678-3921.pab2020.v55.01836

\section{Damage assessment and economic injury level of the two-spotted spider mite Tetranychus urticae in soybean}

\begin{abstract}
The objective of this work was to quantify the reduction of soybean grain yield caused by Tetranychus urticae damage, and to propose an economic injury level (EIL) for this pest in the crop. The experimental design was set up in randomized complete blocks, with four replicates and a $4 \times 2$ factorial arrangement with four levels of mite infestation, with or without mite control. Chlorotic symptoms were evaluated using a damage scale of 1 to 4 . Soybean grain yield, number of pods, number of grains, and 1,000-grain weight were quantified for each segment of plant canopy (lower, middle, and upper) and for the whole plants. The chlorophyll content in the leaves was evaluated using the SPAD index. The population density of one two-spotted spider mite per $\mathrm{cm}^{2}$ of leaf area caused the following reductions: one pod per plant, two grains per plant, $0.7 \mathrm{~g}$ of 1,000-grain weight, and $0.35 \mathrm{~g}$ of grain yield per plant or 42 $\mathrm{kg} \mathrm{ha}^{-1}$. Based on the equation $\mathrm{y}=4,369-41.99 \mathrm{x}$, the EIL of one two-spotted spider mite per $\mathrm{cm}^{2}$ is determined by considering a control cost of US\$20.00 $\mathrm{ha}^{-1}$ and a soybean crop value of US $\$ 350.00 \mathrm{Mg}^{-1}$. As to chlorotic symptoms, the EIL is set between damage scores 1 (no apparent mite damage) and 2 (yellow mottling beginning to appear).
\end{abstract}

Index terms: Glycine max, Tetranychus urticae, control threshold, integrated pest management, Tetranychidae, yield reduction.

\section{Avaliação de dano e nível de dano econômico de ácaro-rajado Tetranychus urticae em soja}

Resumo - O objetivo deste trabalho foi quantificar a redução da produtividade de grãos de soja causada pelos danos de Tetranychus urticae e propor um nível de dano econômico (NDE) para a praga nessa cultura. Utilizou-se o delineamento experimental de blocos ao acaso, com quatro repetições e arranjo fatorial $4 \times 2$ com quatro níveis de infestação pelo ácaro-rajado, com ou sem controle do ácaro. Os sintomas de clorose foram avaliados com notas de 1 a 4. Produtividade de grãos, número de legumes, número de grãos e massa de 1.000 grãos foram quantificados para cada terço do dossel da soja (inferior, médio e superior) e para as plantas inteiras. O teor de clorofila nas folhas de soja foi avaliado por meio do índice SPAD. A densidade populacional de um ácaro-rajado por $\mathrm{cm}^{2}$ de área foliar causou as seguintes reduções: um legume por planta, dois grãos por planta, $0,7 \mathrm{~g}$ da massa de 1.000 grãos e $0,35 \mathrm{~g}$ da produtividade de grãos por planta ou $42 \mathrm{~kg} \mathrm{ha}^{-1}$ de grãos. Com base na equação $\mathrm{y}=4.369-41,99 \mathrm{x}$, o NDE de um ácaro-rajado por $\mathrm{cm}^{2}$ é determinado ao se considerar o custo de controle de US $\$ 20,00 \mathrm{ha}^{-1} \mathrm{e}$ o valor comercial da soja de US\$ $350,00 \mathrm{Mg}^{-1}$. Quanto à descoloração foliar, o NDE situa-se entre as notas de dano 1 (sem descoloração aparente) e 2 (leve descoloração com algumas pontuações amarelas).

Termos para indexação: Glycine max, Tetranychus urticae, limiar de controle, manejo integrado de pragas, Tetranychidae, redução de produtividade. 


\section{Introduction}

Soybean (Glycine max (L.) Merr.) is the major oilseed crop grown and consumed in the world, with a worldwide production of 336.11 million metric tons in the 2019/2020 cropping season, $37 \%$ of which were grown in Brazil (Acompanhamento..., 2020; USDA, 2020). Among the many arthropod pests attacking soybean crops in this tropical/subtropical region, the two-spotted spider mite Tetranychus urticae Koch (Acari: Tetranychidae) stands out due to its high potential to cause damage (Roggia et al., 2008), wide host range (Grbić et al., 2011), and high level of insecticide resistance (Willis, 2017). The increasing occurrence of this pest outbreaks in Brazilian soybean fields has been linked to the following facts: the inappropriate use of pyrethroid insecticides, which leads to the mortality of its natural enemies (Degrande, 1998); as well as to the increased use of fungicides for the control of the soybean rust (Phakopsora pachyrhizi Sydow \& P. Sydow) (Pucciniales: Phakopsoraceae), affecting the population of entomopathogenic fungi that naturally regulates mite populations (Guedes et al., 2007; Roggia, 2010); and to hormesis effect (that is, beneficial development stimulus) caused by the use of sublethal doses of certain insecticide molecules, such as spinetoram (Calabrese \& Baldwin, 2002; Wang et al., 2016). Management strategies for T. urticae are restricted by the lack of information regarding soybean yield loss caused by this pest (Suekane et al., 2012).

Estimated loss of grain yield in soybean plants damaged by the spider mite Mononychellus planki McGregor (Acari: Tetranychidae) were $18.28 \%$ for an average population density of 0.88 mites per $\mathrm{cm}^{2}$ of leaf area (Arnemann et al., 2018). Yield reductions of $40-60 \%$ were reported due to T. urticae attack; however, these estimates were based rather on field reports than on plot trials (Cullen \& Schramm, 2009). Furthermore, the effects of $T$. urticae herbivory on other soybean yield components (as the number of pods, number of grains, and 1,000-grain weight) have not been sufficiently explored yet. Suekane et al. (2012) observed that the number of grains per plant, grain yield, and 1,000-grain weight were significantly influenced by different levels of chlorosis caused by $T$. urticae, but these authors did not analyze these data in relation to different population densities of mites. Net photosynthetic capacity can be severely impaired by T. urticae, even before the loss of chlorophyll content (chlorosis) becomes visually apparent, and ignoring these side effects can lead to underestimations of the pest potential to damage soybean plants (Bueno et al., 2009).

The management of T. urticae on soybean depends primarily upon scouting, action threshold, and acaricide efficiency (Ostlie \& Potter, 2011). In North America, the current threshold for spider mites in soybean is to consider control measures when 20 to $25 \%$ of the leaves are discolored before pod set, and 10 to $15 \%$, after pod set (Gray, 2005). Suekane et al. (2012) also suggest an economic injury level for T. urticae in soybean from 13 to $16 \%$ of chlorotic symptoms; however, the present study was conducted under greenhouse conditions, in which soybean was planted in pots and artificially infested at the reproductive stage R2 (Herman, 1985). The rating of plant injury symptoms provides a practical mean for field scouting and control decision, especially considering the small size of this pest. Nonetheless, injuries caused by drought or foliar diseases can be mistaken as spider mite damage (Wright, 2016), and the percentages of chlorotic symptoms are easily underestimated or overestimated (Ostlie \& Potter, 2011). Additionally, control thresholds based solely on chlorosis ignore the effects of indirect photosynthesis suppression, whereby soybean plants can undergo photosynthetic impairments without displaying the chlorophyll content reduction (Nabity et al., 2009). The density of mites per plant area remains the ideal sampling unit (Higley \& Pedigo, 1993) and could be used to support control thresholds based on leaf injury symptoms. However, we could not find in the literature any research on the determination of an economic injury level for two-spotted spider mites in soybean based on the density of mites per leaf area.

The objective of this work was to quantify the reduction of soybean grain yield caused by $T$. urticae damage, and to propose an economic injury level for this pest in soybean crops.

\section{Materials and Methods}

The experiment was carried out in the municipality of Santa Maria, in the state of Rio grande do Sul, Brazil (29 $72^{\prime} 90^{\prime \prime} \mathrm{S}, 53^{\circ} 75^{\prime} 75^{\prime \prime} \mathrm{W}$, at $110 \mathrm{~m}$ altitude). The climate is classified as Cfa, according to the Köppen-Geiger's climate classification (Alvares et al., 
2013), defined as a humid subtropical climate with hot summers. The soybean cultivar BMX Apolo RR (Brasmax, Cambé, PR, Brazil) was used. It was sowed on 15/11/2014 (120,000 plants ha $\left.{ }^{-1}\right)$. This cultivar was chosen due to its wide use by soybean growers at the time. Infestation by spider mites occurred naturally, and T. urticae represented more than $90 \%$ of the mite population.

The experimental design was carried out in randomized complete blocks with four replicates, and a factorial arrangement $(4 \times 2)$, totalizing eight treatments and 32 plots. Each plot was $4 \times 5 \mathrm{~m}$ large $(8$ soybean rows spaced at $0.5 \mathrm{~m}$ per plot) and contained 120 soybean plants, from which 15 plants were harvested at the end of the crop cycle. There were four levels of mite infestation, quantified according to leaf injury (damage scale ranging from 1 to 4) (Gray, 2005) and its correspondent population densities (twospotted spider mites per $\mathrm{cm}^{2}$ ) (Storck et al., 2012). Each replicate within the four infestation levels included two $4 \times 5 \mathrm{~m}$ plots, one with mite control and the other without mite control.

Leaf injury by $T$. urticae was monitored weekly (20 leaflets per plot) and quantified according to the damage scale proposed by Gray (2005), divided into four damage scores: 1, for normal green leaves, with no apparent mite damage; 2, for paler green leaves, with some evident yellow mottling; 3 , more prevalent yellow mottling, tending to cover the leaf surface with a few necrotic areas; 4, extensively mottled leaves, with numerous necrotic areas. When the whole experimental area reached the damage score 1, the plots designed as treatment 1 (representing the first level of leaf injury and mite infestation) were sprayed with acaricide Abamectin $18 \mathrm{EC}$ at $112 \mathrm{~g} \mathrm{ha}^{-1}$ a.i. (Abamex), to stop the infestation at this level. Infestation was let to grow in the remaining plots until damage score 2, when the same procedure took place in the plots within treatment 2; and so forth. When each replicate (pair of $4 \times 5 \mathrm{~m}$ plots) reached its respective damage score, acaricide was sprayed in one of the plots to interrupt the infestation, while the other was left unsprayed. This way, soybean plants in each treatment were subjected to different levels of $T$. urticae injury, comparing situations with and without mite control.

Sprays were carried out using a $\mathrm{CO}_{2}$-pressurized backpack sprayer, with a $200 \mathrm{~L} \mathrm{ha}^{-1}$ spray volume. Before each spray, T. urticae population density was quantified in the plots that had reached their respective damage scores. The number of mites was counted in $20 \mathrm{~cm}^{2}$ of leaf area, in the underside of the sampled soybean leaflets (20 leaflets per plot), following the methodology proposed by Storck et al. (2012), and the values were then converted to number of mites per $\mathrm{cm}^{2}$. Therefore, a quantitative value of population density was assigned to each damage score $(0.5,1.8$, 11.3, and 28.9 two-spotted spider mites per $\mathrm{cm}^{2}$ for damage scores $1,2,3$, and 4 , respectively).

Since the delimitation of infestation levels depended on the progression of damage scores, sprays were carried out at different moments for each treatment. After the first spray, the plots with mite control were kept mite-free until the end of the crop cycle, with additional Abamectin sprays carried out each 7 to 10day period, according to necessity. Considering that damage score 1 corresponded to no mite damage on leaves and almost zero mite per $\mathrm{cm}^{2}$, this treatment represented the soybean fitness in the absence of mite attack. Defoliating caterpillars were controlled with lunefuron at $7.5 \mathrm{~g} \mathrm{ha}^{-1}$ a.i. (Match) at growth stages V4 and V7 (Herman, 1985), and stinkbugs did not reach the control threshold; thus, the influence of other arthropod pests in the results can be disregarded.

The SPAD (soil-plant analysis development) index was also evaluated for each infestation level, using a portable chlorophyll meter (model SPAD-502, Konica Minolta Optics, Osaka, Japan) to quantify the chlorophyll content in soybean leaves. At the end of the crop cycle, 15 soybean plants were harvested per plot. Grain yield (g per plant) and yield components (number of pods, number of grains, and 1,000-grain weight) were quantified for each segment of the plant canopy (lower, middle, and upper segments), and for whole soybean plants. Mean values from the 15 sampled plants were then calculated for each variable, in their respective plots.

All variables (grain yield, number of pods, number of grains, and 1,000-grain weight) were subjected to variance analysis and to the $\mathrm{F}$ test, at $5 \%$ probability. The means of mite population density were compared through the t-test (LSD) and the regression analysis, and the resulting models described the correlation between T. urticae infestation levels and soybean grain yield components. Statistical analyses were carried out using the softwares Microsoft Excel (Microsoft, 2007) and Sisvar (Ferreira, 2014). Based on the damage 
quantified for each mite per $\mathrm{cm}^{2}$, the economic injury level (EIL) for T. urticae in soybean crops was calculated, employing the following formula (Stern et al., 1959): $\mathrm{EIL}=\mathrm{C} /(\mathrm{V} \times \mathrm{D})$, in which: $\mathrm{EIL}$ is the economic injury level (mites per $\mathrm{cm}^{2}$ ); $\mathrm{C}$ is the control cost of T. urticae (US\$ ha-1); V is the soybean crop market value (US\$ kg-1); and D is the damage or yield loss caused by the pest $\left(\mathrm{kg} \mathrm{ha}^{-1}\right)$.

\section{Results and Discussion}

Leaf damage by $T$. urticae significantly affected the number of pods, number of grains, 1,000-grain weight, and grain yield of the soybean plants. The results from the analyses of variance test indicated significant responses for all variables, according to the variation in the number of T. urticae per $\mathrm{cm}^{2}$ (Tables 1 and 2). All grain yield components showed linear responses to $T$. urticae population growth, except for the 1,000-grain weight. The resulting regression models displayed high coefficients of determination, attesting the representativeness of the models for the relationship between the variables (Figures 1 and 2).

The soybean grain yield decreased following $T$. urticae attack, mainly as a result from reduced pod set and fewer grains (Table 1), corroborating the observations by Ostlie \& Potter (2011). The regression models for the variables number of pods and number of grains indicated that one two-spotted mite per $\mathrm{cm}^{2}$ of leaf area reduced roughly one pod per plant and two grains per plant (Figure 1). Likewise, the model obtained for the variable 1,000-grain weight indicated the approximate loss of $0.7 \mathrm{~g}$ for every two-spotted spider mite per $\mathrm{cm}^{2}$ (Figure 2). The reduction in 1,000-grain weight (that is, smaller grain size) became statistically significant only at high-infestation levels, with more than ten mites per $\mathrm{cm}^{2}$ or damage scores progressing from 3 (11.3 mites per $\mathrm{cm}^{2}$ ) to 4 (28.9 mites per $\mathrm{cm}^{2}$ ) (Table 2 and Figure 2). Suekane et al. (2012) observed a reduction of 0.39 grains per plant and of $1.12 \mathrm{~g}$ in 1,000-grain weight for every percentage point of soybean leaf area damaged by $T$. urticae, whilst the number of pods was not significantly influenced by the different chlorotic symptom levels. However, soybean plants in the aforementioned study were infested with mites at the growth stage R2, when plants had probably set their pods, which could explain the lack of response for this variable.

Chlorophyll content in the leaves was also significantly affected by $T$. urticae herbivory, with a reduction of the SPAD index as population density and damage scores increased (Table 1). The loss of photosynthetic active tissue is one of the main consequences of mite attack in soybean (Ostlie \&

Table 1. Damage score, mean number of Tetranychus urticae per $\mathrm{cm}^{2}$, SPAD (soil plant analysis development) index, mean number of pods and mean number of grains for the lower, middle, and upper segments of the plant canopies, and for the whole soybean plants, on untreated and treated plots with acaricide ${ }^{(1)}$.

\begin{tabular}{|c|c|c|c|c|c|c|c|c|c|c|}
\hline \multirow[t]{2}{*}{ Score } & \multirow[t]{2}{*}{ Mites } & \multirow[t]{2}{*}{ SPAD } & \multicolumn{4}{|c|}{ Number of pods } & \multicolumn{4}{|c|}{ Number of grains } \\
\hline & & & Lower & Middle & Upper & Whole plant & Lower & Middle & Lower & Whole plant \\
\hline & \multicolumn{10}{|c|}{ Without control } \\
\hline 1 & 0.5 & 60.72 & $27.0 \mathrm{a}$ & $54.6 \mathrm{a}$ & $28.9 \mathrm{ab}$ & $110.5 \mathrm{ab}$ & $52.6 \mathrm{a}$ & $107.3 \mathrm{a}$ & $58.4 \mathrm{a}$ & $218.2 \mathrm{a}$ \\
\hline 2 & 1.8 & 53.17 & $29.9 \mathrm{a}$ & $57.5 \mathrm{a}$ & $32.4 \mathrm{a}$ & $119.8 \mathrm{a}$ & $57.6 \mathrm{a}$ & $116.2 \mathrm{a}$ & $61.6 \mathrm{a}$ & $235.4 \mathrm{a}$ \\
\hline 3 & 11.3 & 43.55 & $26.6 \mathrm{a}$ & $53.3 \mathrm{a}$ & $26.7 \mathrm{ab}$ & $106.6 \mathrm{ab}$ & $56.1 \mathrm{a}$ & $110.6 \mathrm{a}$ & $54.5 \mathrm{ab}$ & $221.1 \mathrm{a}$ \\
\hline 4 & 28.9 & 25.76 & $24.8 \mathrm{a}$ & $46.2 \mathrm{a}$ & $22.6 b$ & $93.6 \mathrm{~b}$ & $46.9 \mathrm{a}$ & $92.7 \mathrm{a}$ & $43.4 b$ & $183.0 \mathrm{a}$ \\
\hline \multirow[t]{2}{*}{ Mean } & 10.6 & 45.80 & $26.5 \mathrm{a}$ & 51.2 & 26.3 & 104.0 & 51.7 & 103.2 & 51.7 & 206.7 \\
\hline & \multicolumn{10}{|c|}{ With control ${ }^{(2)}$} \\
\hline 1 & 0.5 & 60.72 & $32.5 \mathrm{a}$ & $62.6 \mathrm{a}$ & $35.3 \mathrm{a}$ & $130.3 \mathrm{a}$ & $63.5 \mathrm{a}$ & $126.8 \mathrm{a}$ & $67.9 \mathrm{a}$ & $258.1 \mathrm{a}$ \\
\hline 2 & 1.8 & 53.17 & $26.3 \mathrm{ab}$ & $55.9 \mathrm{ab}$ & $26.7 \mathrm{~b}$ & $108.9 \mathrm{ab}$ & $54.6 \mathrm{ab}$ & $112.3 \mathrm{a}$ & $54.9 \mathrm{ab}$ & $221.8 \mathrm{ab}$ \\
\hline 3 & 11.3 & 43.55 & $24.2 b$ & $48.0 \mathrm{bc}$ & $24.6 \mathrm{~b}$ & $96.8 \mathrm{~b}$ & $49.4 \mathrm{ab}$ & $102.2 \mathrm{ab}$ & $50.4 \mathrm{~b}$ & $202.0 \mathrm{bc}$ \\
\hline 4 & 28.9 & 25.76 & $22.3 b$ & $42.3 \mathrm{c}$ & $22.2 \mathrm{~b}$ & $86.8 \mathrm{~b}$ & $41.9 \mathrm{~b}$ & $83.1 \mathrm{~b}$ & $42.5 \mathrm{~b}$ & $167.5 \mathrm{c}$ \\
\hline Mean & 10.6 & 45.80 & 25.5 & 50.2 & 26.2 & 101.9 & 50.2 & 101.5 & 51.7 & 203.4 \\
\hline $\mathrm{CV}(\%)^{(3)}$ & - & - & 19.76 & 18.29 & 18.74 & 17.55 & 20.85 & 19.26 & 19.64 & 18.41 \\
\hline
\end{tabular}

${ }^{(1)}$ Means followed by equal, lowercase letters within untreated and treated plots, do not differ, by the t-test, at $5 \%$ probability. ${ }^{(2)}$ Plots with control protected from mite infestation by weekly Abamectin $\left(112 \mathrm{~g} \mathrm{ha}^{-1}\right.$ a.i.) sprays. ${ }^{(3)} \mathrm{CV}$, coefficient of variation. 
Potter, 2011). The decrease of chlorophyll content was quite expressive, with more than one unit of SPAD index reduced for every two-spotted spider mite per $\mathrm{cm}^{2}$ (Figure 2). Plants under damage score 4 (28.9 mites per $\left.\mathrm{cm}^{2}\right)$ showed an average SPAD as low as 25.76, far below the level considered ideal for high-grain yield in soybean crops, which is around 40 during growing stages, and 50, during grain filling (Yokoyama et al., 2018).

As to the variable grain yield, the regression model indicated a reduction of $0.35 \mathrm{~g}$ of grain yield per plant for every two-spotted spider mite per $\mathrm{cm}^{2}$ (Figure 2). Consequently, an average population density of one two-spotted spider mite per $\mathrm{cm}^{2}$ of soybean leaf area resulted in a yield reduction of $42 \mathrm{~kg} \mathrm{ha}^{-1}$ (Figure 3). Based on the equation $\mathrm{y}=4,369-41.99 \mathrm{x}$, an economic injury level was determined for T. urticae in soybean crops, with corresponding variations according to the control cost and soybean crop value (Table 3). Considering the control cost of US\$ $20.00 \mathrm{ha}^{-1}$, and soybean crop value of US\$ $350.00 \mathrm{Mg}^{-1}$, the EIL was reached at one two-spotted spider mite per $\mathrm{cm}^{2}$. For injury symptoms, this EIL (one mite per $\mathrm{cm}^{2}$ ) was set at the transition from damage score 1 ( 0.5 mites per $\mathrm{cm}^{2}$, no apparent mite damage) to score 2 (1.8 mites per $\mathrm{cm}^{2}$, paler green leaves, with some yellow mottling) that is, at the very beginning of the infestation.
In comparison, other authors recommend mite control when leaf discoloration is higher than $15 \%$, possibly allowing the infestation to reach and surpass damage score 2 (Cullen \& Schramm, 2009; Suekane et al., 2012). However, Gray (2005) observed that the physiological stress on soybean plants attacked by $T$. urticae increases dramatically from damage score 2 onwards: leaves rated as 4 show photosynthetic capacity three times lower than leaves rated as 1, and half as much chlorophyll. Similar results were found in the present study, in which the SPAD index decreased from 60.73 , on leaves rated as 1 , to 25.76 on leaves rated as 4 . This physiological response supports the recommendation to apply control measures at the infestation onset, preventing soybean plants from reaching damage scores equal or higher than 2 .

As pointed out by Suekane et al. (2012), a damage level of about $15 \%$ of leaf discoloration due to mite attack could be considered acceptable, as it is the approximate leaf-area damage tolerated by soybean plants according to Tecnologias... (2006). However, this percentage of tolerable damage varies according to the total leaf area index (LAI) of each soybean cultivar, increasing in plants with higher LAI, and decreasing in plants with lower LAI (Sediyama et al., 2015). Furthermore, there are other mechanisms leading to yield reduction in soybean plants under arthropod

Table 2. Damage score, mean number of Tetranychus urticae per $\mathrm{cm}^{2}, 1,000$-grain weight, and grain yield of the lower, middle, and upper segments of the canopies and of the whole soybean plants, on untreated and treated plots with acaricide ${ }^{(1)}$.

\begin{tabular}{|c|c|c|c|c|c|c|c|c|}
\hline \multirow[t]{2}{*}{ Score } & \multirow[t]{2}{*}{ Mite } & \multicolumn{3}{|c|}{ 1,000-grain weight (g) } & \multicolumn{4}{|c|}{ Grain yield (g per plant ) } \\
\hline & & Lower & Middle & Upper & Lower & Middle & Upper & Whole plant \\
\hline & \multicolumn{8}{|c|}{ Without control } \\
\hline 1 & 0.5 & $167.0 \mathrm{a}$ & $171.4 \mathrm{a}$ & $155.1 \mathrm{a}$ & 7.9a & $17.6 \mathrm{a}$ & $8.1 \mathrm{ab}$ & $33.7 \mathrm{a}$ \\
\hline 2 & 1.8 & $165.1 \mathrm{a}$ & $168.8 \mathrm{a}$ & $152.4 \mathrm{a}$ & $9.6 \mathrm{a}$ & $18.5 \mathrm{a}$ & $9.1 \mathrm{a}$ & $37.2 \mathrm{a}$ \\
\hline 3 & 11.3 & $171.1 \mathrm{a}$ & $171.2 \mathrm{a}$ & $159.1 \mathrm{a}$ & $9.7 \mathrm{a}$ & $17.1 \mathrm{a}$ & $8.7 \mathrm{a}$ & $35.5 \mathrm{a}$ \\
\hline 4 & 28.9 & $144.7 \mathrm{~b}$ & $142.4 \mathrm{~b}$ & $124.7 \mathrm{~b}$ & $8.1 \mathrm{a}$ & $15.1 \mathrm{a}$ & $5.7 \mathrm{~b}$ & $28.9 \mathrm{a}$ \\
\hline \multirow[t]{2}{*}{ Mean } & 10.6 & 158.2 & 158.7 & 142.7 & 8.6 & 16.6 & 7.4 & 32.6 \\
\hline & \multicolumn{8}{|c|}{ With control ${ }^{(2)}$} \\
\hline 1 & 0.5 & $168.5 \mathrm{a}$ & $168.5 \mathrm{a}$ & $147.5 \mathrm{a}$ & $10.3 \mathrm{a}$ & $20.3 \mathrm{a}$ & $8.3 \mathrm{a}$ & $39.0 \mathrm{a}$ \\
\hline 2 & 1.8 & $165.3 \mathrm{a}$ & $166.6 \mathrm{a}$ & $148.9 \mathrm{a}$ & $8.4 \mathrm{ab}$ & $16.8 \mathrm{ab}$ & $8.1 \mathrm{a}$ & $33.3 \mathrm{ab}$ \\
\hline 3 & 11.3 & $165.7 \mathrm{a}$ & $165.6 \mathrm{a}$ & $149.5 \mathrm{a}$ & $8.2 \mathrm{ab}$ & $16.4 \mathrm{ab}$ & 7.0ab & $31.5 \mathrm{ab}$ \\
\hline 4 & 28.9 & $149.8 \mathrm{~b}$ & $149.2 \mathrm{~b}$ & $130.8 \mathrm{~b}$ & $5.8 \mathrm{~b}$ & $11.8 \mathrm{~b}$ & $5.3 \mathrm{~b}$ & $23.0 \mathrm{~b}$ \\
\hline Mean & 10.6 & 159.8 & 159.8 & 141.5 & 7.7 & 15.4 & 6.8 & 30.0 \\
\hline $\mathrm{CV}(\%)^{(3)}$ & - & 6.04 & 6.55 & 6.82 & 30.25 & 27.17 & 27.75 & 25.61 \\
\hline
\end{tabular}

${ }^{(1)}$ Means followed by equal, lowercase letters within untreated and treated plots, do not differ, by the t-test, at $5 \%$ probability. ${ }^{(2)} \mathrm{Plots}$ with control protected from mite infestation by weekly Abamectin $\left(112 \mathrm{~g} \mathrm{ha}^{-1}\right.$ a.i.) sprays. ${ }^{(3)} \mathrm{CV}$, coefficient of variation. 
attack, besides loss of photosynthetic surface (Bueno et al., 2009; Nabity et al., 2009), which restricts the reliability of chlorosis as a sole indicator of mite injury. Thus, the rating of plant injury symptoms should be supported by surveys on the mite density per leaf area, to reach more assertive control decisions.

Both plots with and plots without mite control showed very similar results, indicating that the control was not effective and did not influence the grain yield and its components significantly. A decreasing efficacy of acaricide applications in the field was
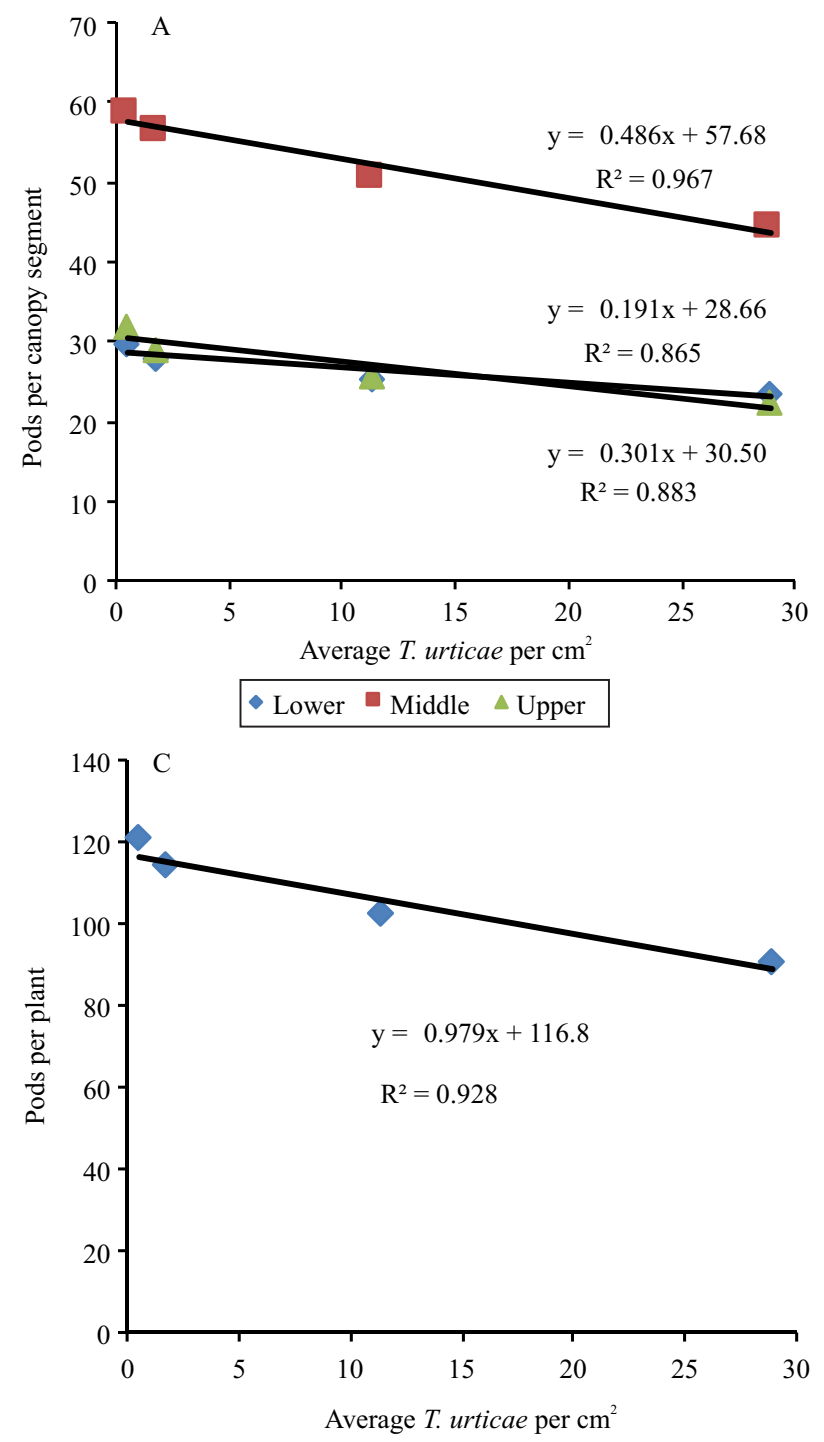

reported by Wright (2016), according to whom the rate slowing of population increase can be performed with an acaricide application in many cases, mainly in T. urticae. Such control failures might be one of the causes for the observed lack of response. However, the economic injury level obtained (about one mite per $\mathrm{cm}^{2}$, ranging from 0.24 to 1.52 mites per $\mathrm{cm}^{2}$ ) suggests that the mite control began too late, when damage was already significant and irreversible. Bueno et al. (2009) also observed that $T$. urticae can cause significant yield losses in soybean even in lower infestation. For
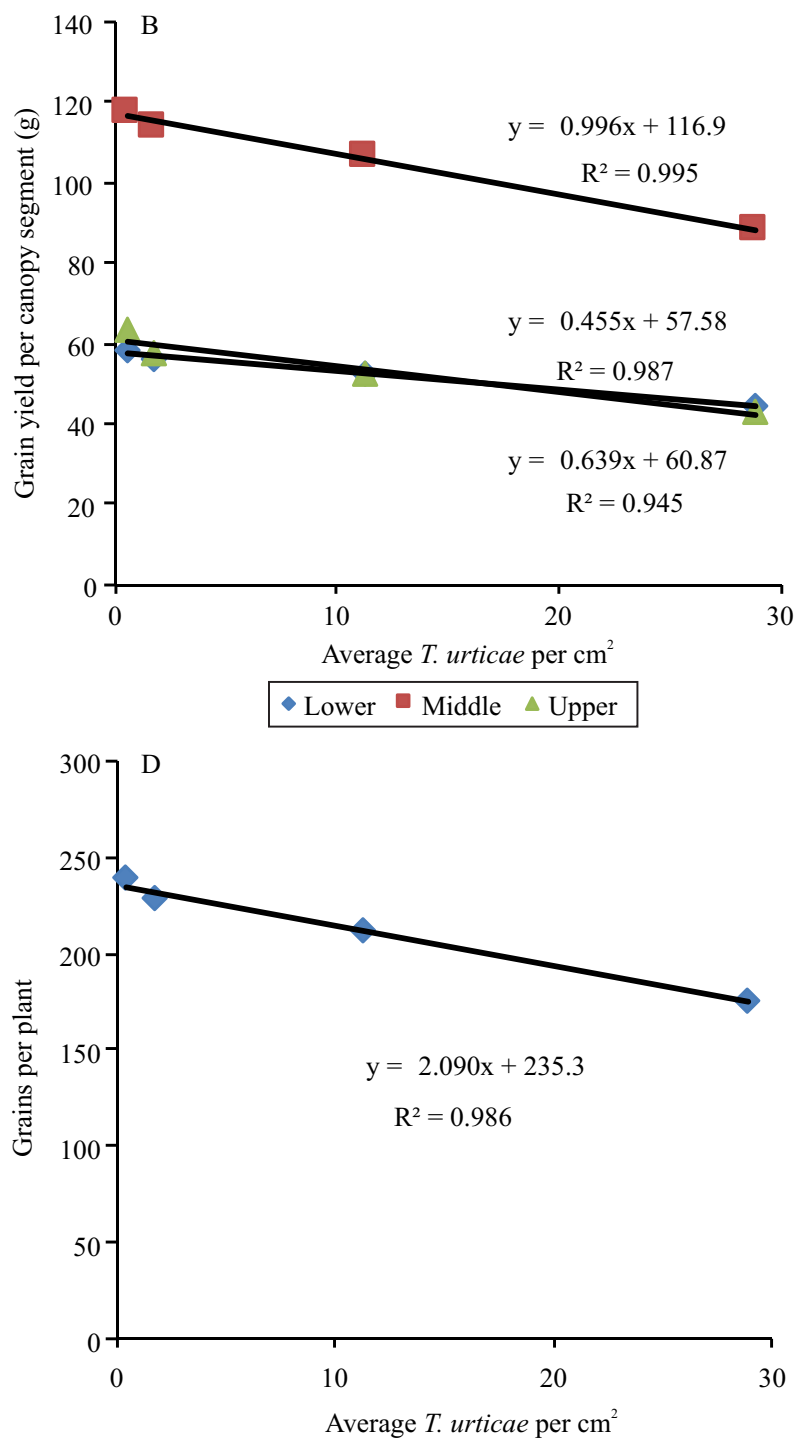

Figure 1. Relationship between T. urticae population density (number of mites per $\mathrm{cm}^{2}$ of leaf surface) and the soybean yield components number of pods (A and C) and number of grains (B and D), for each segment of plant canopies (lower, middle, and upper; top row) and for whole plants. 
the soybean plants rated as 1 in the damage scale $(0.5$ mites per $\mathrm{cm}^{2}$ ), there was a slight maintenance of productivity in the absence of mites (Tables 1 and 2), which agrees with the EIL proposed and highlights the need to stop the mite infestation before damage score 2 was reached.

The middle and upper segments of the canopies displayed a higher susceptibility to T. urticae attack. All variables showed the following susceptibility
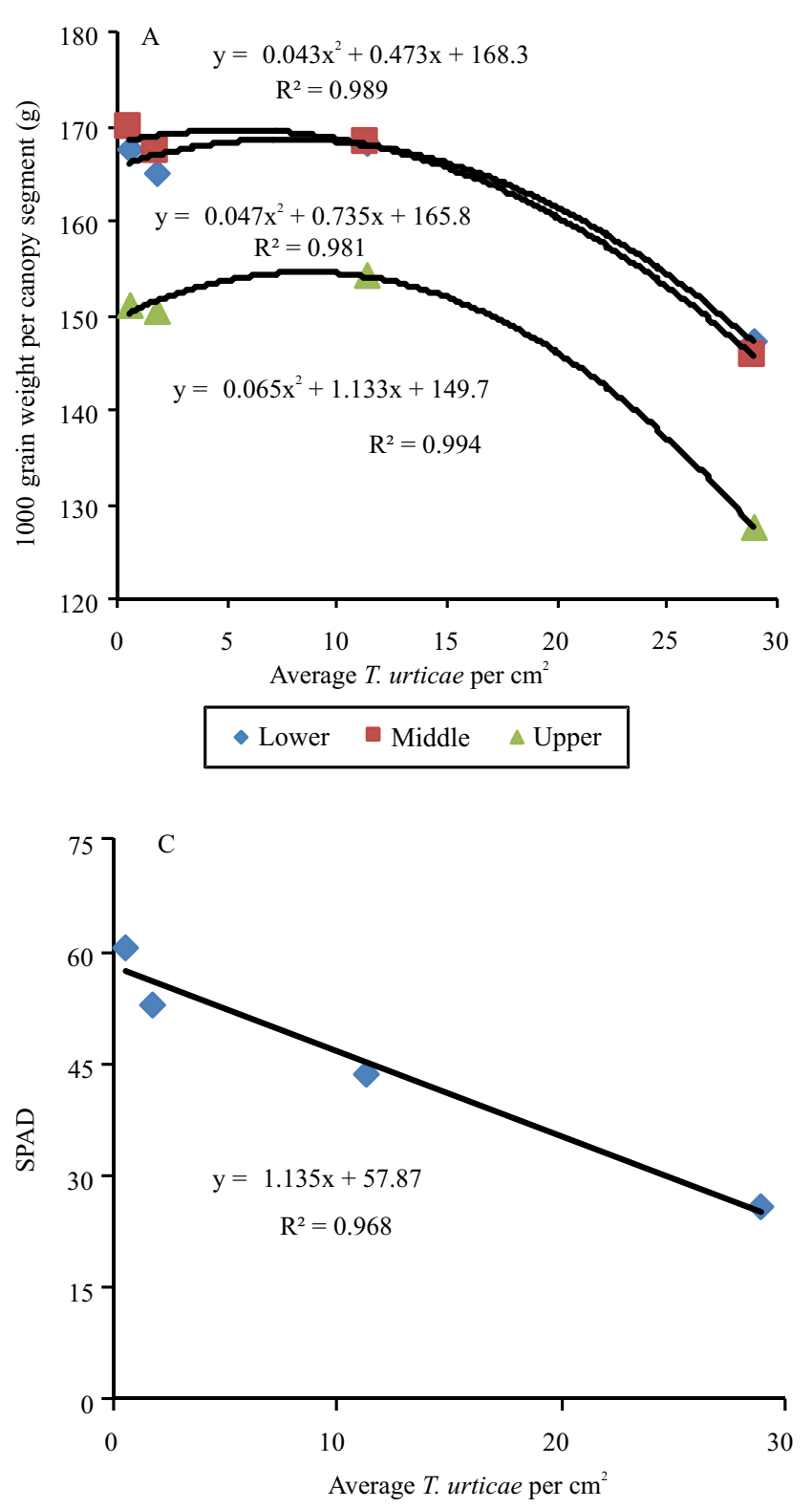

pattern: middle segment $>$ upper segment $>$ lower segment. It took two mites per $\mathrm{cm}^{2}$ to reduce one pod in the middle canopy, for instance, and 5.2 mites per $\mathrm{cm}^{2}$ to reduce the same pod in the lower canopy (Figure 1). Likewise, 5.7 mites were needed in the middle canopy to reduce $1 \mathrm{~g}$ of grain yield, in contrast to 14 mites in the lower canopy (Figure 2). Since grain filling and maturation in soybean plants progress upwards, the upper parts of the canopy are
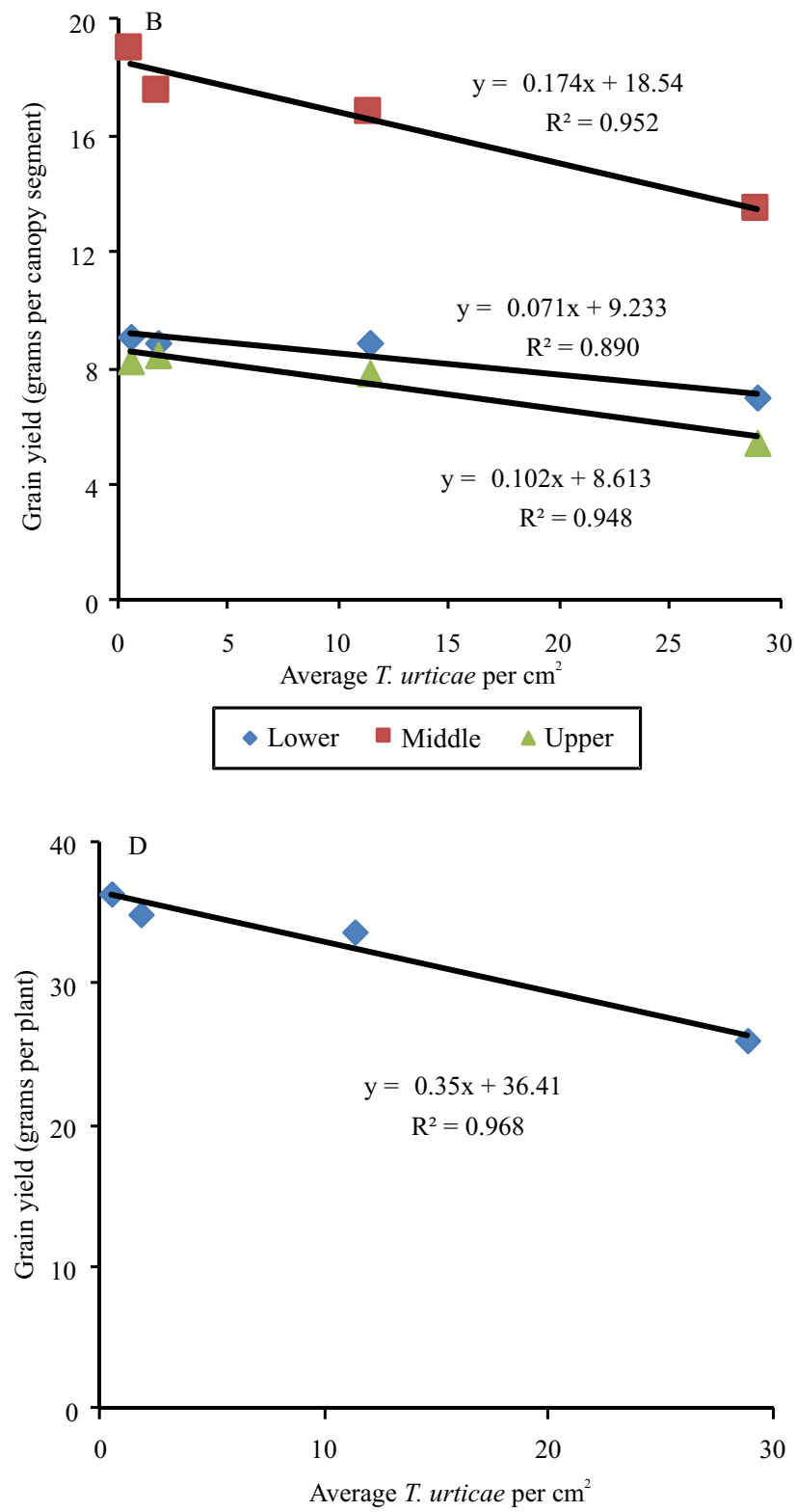

Figure 2. Relationship between Tetranychus urticae population density (number of mites per $\mathrm{cm}^{2}$ of leaf surface), 1000 -grain weight (g), SPAD index, and soybean grain yield (g) for each segment of plant canopy (lower, middle and upper; top row) and for whole plants (bottom row). 
more prone to reflect the stress suffered during the cycle, which can explain this pattern (Herman, 1985). Therefore, plant protection against mites should be strengthened from the middle to the end of the crop cycle, when soybean plants are forming leaves of the middle and upper canopy segments and shifting from the vegetative to the reproductive stage.

Other authors suggested also the interval from growth stages R1 to R5 as the most critical for mite protection in soybean (Cullen \& Schramm, 2009; Ostlie \& Potter, 2011). Another study shows that the highest growth rates for mites on soybean occurred

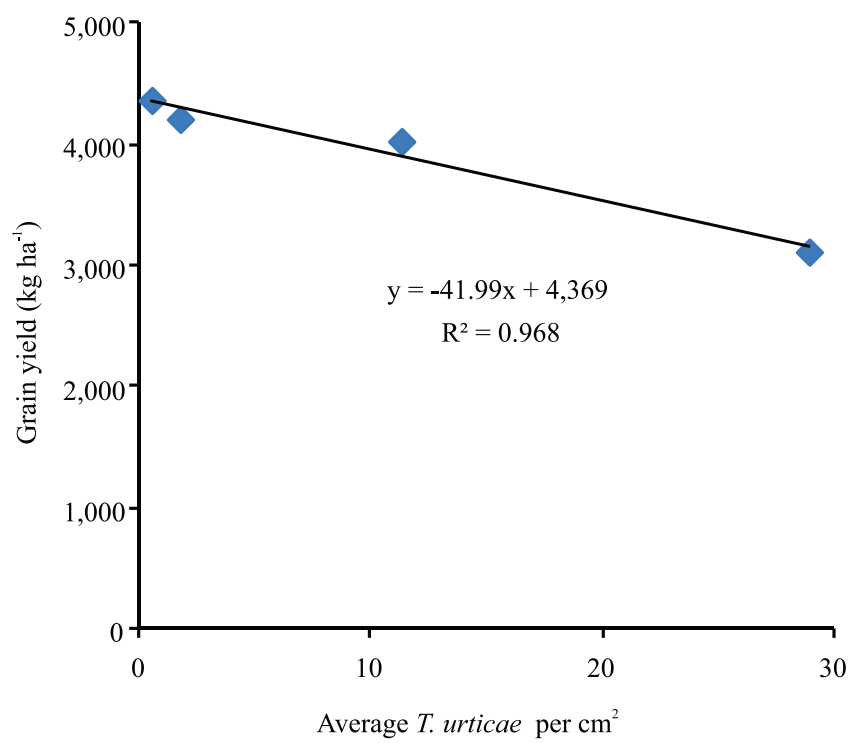

Figure 3. Relationship between Tetranychus urticae population density (number of mites per $\mathrm{cm}^{2}$ of leaf surface) and soybean grain yield.

Table 3. Variation of economic injury level (average number of Tetranychus urticae per $\mathrm{cm}^{2}$ ) in relation to soybean crop value and T. urticae control cost, considering $90 \%$ of control efficiency.

\begin{tabular}{lcccc}
\hline \multirow{2}{*}{$\begin{array}{l}\text { Control cost } \\
(\mathrm{US \$} \mathrm{ha-1})\end{array}$} & \multicolumn{4}{c}{ Soybean crop value $\left(\mathrm{US \$} \mathrm{Mg}^{-1}\right)$} \\
\cline { 2 - 5 } ) & 250.00 & 300.00 & 350.00 & 400.00 \\
\hline 5.00 & 0.38 & 0.32 & 0.27 & 0.24 \\
7.50 & 0.57 & 0.48 & 0.41 & 0.36 \\
10.00 & 0.76 & 0.63 & 0.54 & 0.48 \\
12.50 & 0.95 & 0.79 & 0.68 & 0.60 \\
15.00 & 1.14 & 0.95 & 0.82 & 0.71 \\
20.00 & 1.52 & 1.27 & 1.09 & 0.95 \\
\hline
\end{tabular}

after the beginning of flowering (growth stage R1) (Arnemann et al., 2015). In addition, T. urticae infestations typically begin in the lower canopy of soybean plants, and progress upwards leading to leaf dropping off, as colonies grow and injury intensifies (Cullen \& Schramm, 2009). The susceptibility pattern found in the present work (middle $>$ upper $>$ lower) corroborates the observations by Ostlie \& Potter (2011), who set a spray threshold for T. urticae on soybean, when mite colonies progress from the lower to the middle canopy, with scattered colonies in the upper segment. These findings highlight the importance of a good insecticide-spray coverage which should uniformly reach all segments of the soybean canopy.

Therefore, in order to safeguard the high-grain yield potential of modern soybean cultivars, T. urticae should be properly managed at the very beginning of infestation, even before leaf injuries become fully apparent. The information provided here can help soybean growers and field technicians to reach more assertive decisions regarding T. urticae management in soybean cultivations. Further studies should replicate this damage assessment under different field conditions.

\section{Conclusions}

1. The economic injury level for T. urticae in soybean based on population density is one two-spotted spider mite per $\mathrm{cm}^{2}$ of leaf area, considering the control cost of US\$ $20.00 \mathrm{ha}^{-1}$ and the soybean crop value of US\$ $350.00 \mathrm{Mg}^{-1}$.

2. The economic injury level for $T$. urticae in soybean based on leaf injury is between damage score 1 (no apparent mite damage) to score 2 (paler green leaves with some yellow mottling).

3. The middle segment of the soybean canopy is more susceptible to T. urticae damage, followed by the upper segment.

\section{References}

ACOMPANHAMENTO DA SAFRA BRASILEIRA [DE] GRÃOS: safra 2019/20: décimo levantamento, v.7, n.10, jul. 2020. Available at: <https:/www.conab.gov.br/info-agro/safras/graos/ boletim-da-safra-de-graos>. Accessed on: Aug. 122020.

ALVARES, C.A.; STAPE, J.L.; SENTELHAS, P.C.; GONÇALVES, J.L. de M.; SPAROVEK, G. Köppen's climate classification map for Brazil. Meteorologische Zeitschrift, v.22, p.711-728, 2013. DOI: https://doi.org/10.1127/09412948/2013/0507. 
ARNEMANN, J.A.; FIORIN, R.A.; GUEDES, J.V.C.; POZEBON, H.; MARQUES, R.P.; PERINI, C.R.; STORCK, L. Assessment of damage caused by the spider mite Mononychellus planki (McGregor) on soybean cultivars in South America. Australian Journal of Crop Science, v.12, p.1989-1996, 2018. DOI: https://doi.org/10.21475/ajcs.18.12.12.p1434.

ARNEMANN, J.A.; FIORIN, R.A.; PERINI, C.R.; STORCK, L.; CURIOLETTI, L.E.; NACHMAN, G.; GUEDES, J.V.C. Density and growth rates of spider mites in relation to phenological stages of soybean cultivars in Brazil. Experimental and Applied Acarology, v.67, p.423-440, 2015. DOI: https://doi.org/10.1007/ s10493-015-9958-4.

BUENO, A. de F.; BUENO, R.C.O. de F.; NABITY, P.D.; HIGLEY, L.G.; FERNANDES, A.O. Photosynthetic response of soybean to twospotted spider mite (Acari: Tetranychydae) injury. Brazilian Archives of Biology and Technology, v.52, p.825-834, 2009. DOI: https://doi.org/10.1590/S1516-89132009000400005.

CALABRESE, E.J.; BALDWIN, L.A. Defining hormesis. Human \& Experimental Toxicology, v.21, p.91-97, 2002. DOI: https://doi.org/10.1191/0960327102ht217oa.

CULLEN, E.; SCHRAMM, S. Two-spotted spider mite management in soybean and corn. Madison: University of Wisconsin Extension, 2009. Available at: <http://corn.agronomy. wisc.edu/Management/pdfs/A3890.pdf>. Accessed on: Mar. 20 2020.

DEGRANDE, P.E. Manejo integrado de pragas do algodoeiro. 1998. Available at: <https://www.infoteca.cnptia.embrapa.br/ handle/doc/241158>. Accessed on: Mar. 202019.

FERREIRA, D.F. Sisvar: a guide for its bootstrap procedures in multiple comparisons. Ciência e Agrotecnologia, v.38, p.109-112, 2014. DOI: https://doi.org/10.1590/S1413-70542014000200001.

GRAY, M. Twospotted spider mite infestations in soybeans intensify as drought conditions persist. [Illinois]: University of Illinois Extension, 2005. Available at: <http://bulletin.ipm. illinois.edu/print.php?id=354>. Accessed on: Mar. 202019.

GRBIĆ, M.; LEEUWEN, T. van; CLARK, R.M.; ROMBAUTS, S.; ROUZÉ, P.; GRBIĆ, V.; OSBORNE, E.J.; DERMAUW, W.; THI NGOC, P.C.; ORTEGO, F.; HERNÁNDEZ-CRESPO, P.; DIAZ, I.; MARTINEZ, M.; NAVAJAS, M.; SUCENA, É.; MAGALHÃES, S.; NAGY, L.; PACE, R.M.; DJURANOVIĆ, S.; SMAGGHE, G.; IGA, M.; CHRISTIAENS, O.; VEENSTRA, J.A.; EWER, J.; VILLALOBOS, R.M.; HUTTER, J.L.; HUDSON, S.D.; VELEZ, M.; YI, S. V.; ZENG, J.; PIRES-DASILVA, A.; ROCH, F.; CAZAUX, M.; NAVARRO, M.; ZHUROV, V.; ACEVEDO, G.; BJELICA, A.; FAWCETT, J.A.; BONNET, E.; MARTENS, C.; BAELE, G.; WISSLER, L.; SANCHEZ-RODRIGUEZ, A.; TIRRY, L.; BLAIS, C.; DEMEESTERE, K.; HENZ, S.R.; GREGORY, T.R.; MATHIEU, J.; VERDON, L.; FARINELLI, L.; SCHMUTZ, J.; LINDQUIST, E.; FEYEREISEN, R.; PEER, Y. van de. The genome of Tetranychus urticae reveals herbivorous pest adaptations. Nature, v.479, p.487-492, 2011. DOI: https://doi.org/10.1038/nature10640.

GUEDES, J.V.C.; NAVIA, D.; LOFEGO, A.C.; DEQUECH, S.T.B. Ácaros associados à cultura da soja no Rio Grande do
Sul. Neotropical Entomology, v.36, p.288-293, 2007. DOI: https://doi.org/10.1590/S1519-566X2007000200017.

HERMAN, J.C. (Ed.). How a soybean plant develops. Ames: Iowa State University of Science and Technology Cooperative Extension Service, 1985. 20p. (Special Report, 53).

HIGLEY, L.G.; PEDIGO, L.P. Economic injury level concepts and their use in sustaining environmental quality. Agriculture, Ecosystems \& Environment, v.46, p.233-243, 1993. DOI: https://doi.org/10.1016/0167-8809(93)90027-M.

MICROSOFT. Microsoft Office Excel 2007. version 12.0. [S.1.]: Microsoft Corporation, 2007.

NABITY, P.D.; ZAVALA, J.A.; DELUCIA, E.H. Indirect suppression of photosynthesis on individual leaves by arthropod herbivory. Annals of Botany, v.103, p.655-663, 2009. DOI: https://doi.org/10.1093/aob/mcn127.

OSTLIE, K.; POTTER, B. Managing two-spotted spider mites on soybeans. [Minnesota]: University of Minnesota Extension, 2011. Available at: <https://www.ag.ndsu.edu/extensionentomology/ field-crops-insect-pests/Documents/soybean/managing-twospotted-spider-mites-on-soybeans>. Accessed on: Mar. 202019.

ROGGIA, S. Caracterização de fatores determinantes dos aumentos populacionais de ácaros tetraniquídeos em soja. 2010. 154p. Tese (Doutorado) - Escola Superior de Agricultura Luiz de Queiroz, Universidade de São Paulo, Piracicaba.

ROGGIA, S.; GUEDES, J.V.C.; KUSS, R.C.R.; ARNEMANN, J.A.; NÁVIA, D. Spider mites associated to soybean in Rio Grande do Sul, Brazil. Pesquisa Agropecuária Brasileira, v.43, p.295-301, 2008. DOI: https://doi.org/10.1590/S0100$204 X 2008000300002$.

SEDIYAMA, T.; SILVA, F.; BORÉM, A. (Ed.). Soja: do plantio à colheita. Viçosa: UFV, 2015. 333p.

STERN, V.M.; SMITH, R.F.; VAN DEN BOSCH, R.; HAGEN, K.S. The integration of chemical and biological control of alfalfa aphid: the integrated control concept. Hilgardia, v.29, p.81-101, 1959. DOI: https://doi.org/10.3733/hilg.v29n02p081.

STORCK, L; FIORIN, R.A.; CARGNELUTTI FILHO, A; GUEDES, J.V.C. A sampling procedure for quantifying mites in soybeans. Experimental and Applied Acarology, v.57, p.117126, 2012. DOI: https://doi.org/10.1007/s10493-012-9547-8.

SUEKANE, R.; DEGRANDE, P.E.; MELO, E.P. de; BERTONCELLO, T.F.; LIMA JUNIOR, L. dos S. de; KODAMA, C. Damage level of the twos-potted spider mite Tetranychus urticae Koch (Acari: Tetranychidae) in soybeans. Revista Ceres, v.59, p.77-81, 2012. DOI: https://doi.org/10.1590/S0034737X2012000100011.

TECNOLOGIAS de produção de soja - Região central do Brasil 2007. Londrina: Embrapa Soja: Embrapa Cerrados: Embrapa Agropecuária Oeste, 2006. 225p. (Embrapa Soja. Sistemas de produção, 11).

USDA. United States Department of Agriculture. World Agricultural Production. 2020. Available at: <https://apps.fas. usda.gov/psdonline/circulars/production.pdf $>$. Accessed on: Aug. 122020 . 
WANG, L.; ZHANG, Y.; XIE, W.; WU, Q.; WANG, S. Sublethal effects of spinetoram on the two-spotted spider mite, Tetranychus urticae (Acari: Tetranychidae). Pesticide Biochemistry and Physiology, v.132, p.102-107, 2016. DOI: https://doi.org/10.1016/j. pestbp.2016.02.002.

WILLIS, K.J. (Ed.). State of the World's Plants 2017. Kew: Royal Botanic Gardens, 2017. 96p. Report.

WRIGHT, R. Managing spider mites in corn and soybean: treatment threshold. [Nebraska]: University of Nebraska, 2016.
Available at: $\quad<$ https://cropwatch.unl.edu/managing-spidermites-corn-and-soybean-thresholds-treatments-unl-cropwatchjuly-25-2>. Accessed on: Mar. 202019.

YOKOYAMA, A.H.; RIBEIRO, R.H.; BALBINOT JUNIOR, A.A.; FRANCHINI, J.C.; DEBIASI, H.; ZUCARELI, C. Índices de área foliar e SPAD da soja em função de culturas de entressafra e nitrogênio e sua relação com a produtividade. Revista de Ciências Agrárias, v.41, p.953-962, 2018. DOI: https://doi.org/10.19084/RCA18153. 